\title{
Object Segmentation on UAV Photo Data to Support the Provision of Rural Area Spatial Information
}

\author{
Nurwita Mustika Sari and Dony Kushardono \\ Pusat Pemanfaatan Penginderaan Jauh \\ Jl. Kalisari no. 8 Pekayon, Pasar Rebo, Jakarta Timur 13710 \\ Lembaga Penerbangan dan Antariksa Nasional \\ Corresponding E-mail: nurwita.mustika@lapan.go.id
}

\begin{abstract}
The use of Unmanned Aerial Vehicle (UAV) to take aerial photographs is increasing in recent years. Photo data taken by UAV become one of reliable detailed-scale remote sensing data sources. The capability to obtain cloud-free images and the flexibility of time are some of the advantages of UAV photo data compared to satellite images with optical sensor. Displayed area at the data shows the objects clearly. Rural area has certain characteristics in its land cover namely ricefield. To delineate the area correctly there is an object-based image analysis methods (OBIA) that could be applied. In this study, proposed a novel method to execute the separation of objects that exist in the data with segmentation method. The result shows an effective segmentation method to separate different objects in rural areas recorded on UAV image data. The accuracy obtained is $90.47 \%$ after optimization process. This segmentation can be a valid basis to support the provision of spatial information in rural area.
\end{abstract}

Keywords: UAV aerial photos, object-based image analysis, segmentation, rural area

\begin{abstract}
Abstrak
Penggunaan Unmanned Aerial Vehicle (UAV) untuk mengambil foto udara meningkat dalam beberapa tahun terakhir. Data foto yang diambil oleh UAV menjadi salah satu rinci skala sumber data penginderaan jauh yang dapat diandalkan. Kemampuan untuk mendapatkan gambar bebas awan dan fleksibilitas waktu pengambilan adalah beberapa keuntungan data foto UAV dibandingkan dengan citra satelit dengan sensor optik. Daerah ditampilkan di data dapat menunjukkan objek dengan jelas. Daerah pedesaan memiliki karakteristik tutupan lahan tertentu yakni persawahan. Untuk membatasi daerah dengan benar ada metode analisis citra berbasis obyek (OBIA) yang bisa diterapkan. Dalam penelitian ini, diusulkan metode baru untuk melaksanakan pemisahan obyek-obyek yang ada dengan metode segmentasi. Hasil penelitian menunjukkan metode segmentasi yang efektif untuk memisahkan objek yang berbeda di daerah pedesaan tercatat pada data citra UAV. Akurasi yang diperoleh adalah $90,47 \%$ setelah proses optimasi. Segmentasi ini dapat menjadi dasar yang valid untuk mendukung penyediaan informasi spasial di daerah pedesaan.
\end{abstract}

Kata kunci: foto udara UAV, analisis citra berbasis obyek, segmentasi, daerah pedesaan

\section{Introduction}

Several types of satellite imagery with optical sensor which has a high resolution are exist, for example Pleaides, WorldView, RapidView. While the ones commonly used in Indonesia are Ikonos and Quickbird which are two types of optical satellite imagery with high-resolution. Both are fairly easy to obtain and their display picture is quite sharp so that they are often used in detailed scale mapping. However, high-resolution satellite imagery which has been used until now has many limitations such as the the cloud cover, high price, the dependence on data providers, the less flexible recording time and the inflexible data location (Shofiyati, 2011).
A number of weaknesses of optical satellite imagery make many people look for alternative providers of remote sensing data of detailed scale such as photo data. Hartono (2010) writes about the strength of the aerial photographs which is capable of presenting the data of the earth's surface in detail. Aerial photo scale 1: 20,000 has been able to show pine stands (Sahid, 2009). Other Applied aerial photo processing is done Muryani (2010) for the analysis of changes in the coastline. Aerial photographs can be taken also by using unmanned aircraft (UAV). Dony (2014) reveales that the recording of remote sensing data with UAVs has several advantages such as the less expensive operational and investment costs and the short time to acquire data. In addition, the 
recording time is also more flexible. By making distance much closer and using recording tools with adequate specifications, scale is obtained with much more details. Besides, UAV's ability to fly under a cloud produces cloud-free images which is more detail and sharper.

Khomarudin et al. (2014) also reveals about how UAV data are able to assist in the evaluation of the disasters, especially floods and analysis of risk reduction. In addition, the rapid development of the UAV makes it as a common tool used by structure geologists for a detailed mapping (Bemis et al., 2014). Current usage of UAV data become a way for taking photograph of ricefield terraces and perform a classification on the terraces with the help of data Digital Surface Model (DSM) (Diaz-Varela et al., 2014).

The way applied to get an information from remote sensing data with detailed scale is using pixel-based method which is rather impossible to applied for the UAV data. This is because the process of extracting information on a detailed scale image data is difficult. Now the object-based image processing is a good option to separate objects at a high resolution image, in this research is the UAV image data, because if you use pixel-based processing, the extraction of a specific object in the image will fail (Xiaoxia et al., 2005).

Marpu (2009) discusses a more advanced image analysis. We need a way to separate objects more accurately. This method is called OBIA(Object Based Image Analysis). This method will separate the object according to the homogeneity of the character of an object such as shape, pattern and texture. Application of OBIA for high and medium resolution imagery has been applied in several studies conducted by Flanders et al. (2003) who applies the Landsat 7 ETM + area identification for young, old, forests, bodies of water, urban and Gao et al. (2007) who applies the forest areas on Landsat imagery. Object-based image analysis is closely related to the separation of objects in an image which can be done by segmentation. Parsa (2013) investigates the optimization of the segmentation parameters in particular Landsat data for ricefield mapping. UAV data processing has also been done in Sari and Dony's research (2014) where it is conducted based on land

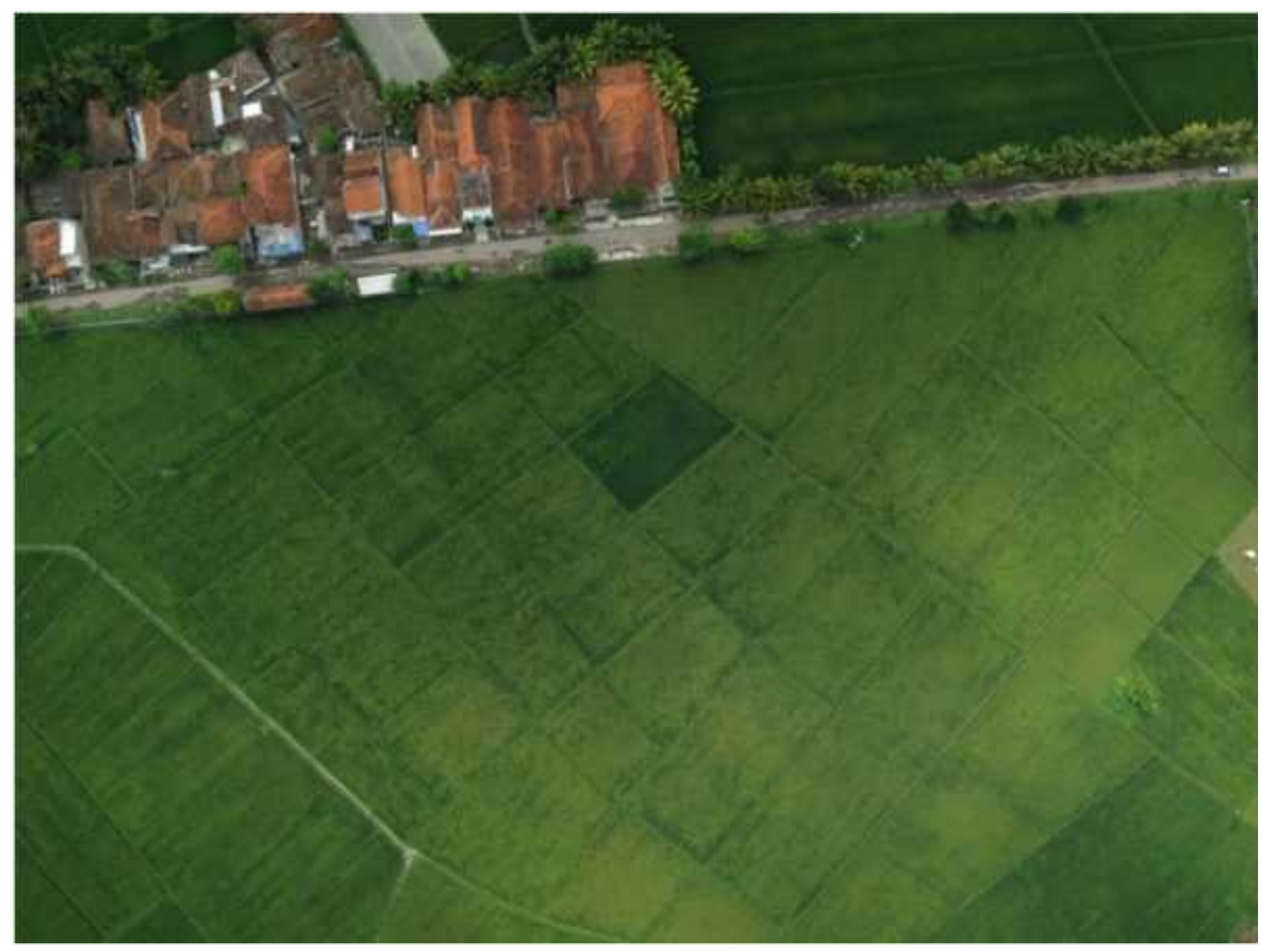

Figure 1. LSU-1 image data used for testing 
cover classification of objects in the data UAV with the accuracy of $95.22 \%$ by the proposed method using texture features.

Spatial planning is a unitary stage for planning the spaces, the utilization of space, and space utilization control activities. Spatial structure of rural areas is closely related to development of rural areas where the support of a detailed scale remote sensing data used for mapping becomes something crucial. Rural areas itself is a region that has a major agricultural activities, including the management of natural resources and its area functions are as rural area, government services, social services, and economic activities. For the implementation of effective spatial planning, it is required a detail scale map.

Bappenas (2010) explaines that the development of rural areas greatly affects the national development because $52 \%$ of Indonesia's population live in rural areas and $63.5 \%$ of the poor live in rural areas. Most of the people in rural areas depend on agricultural sector for their daily lives, but the lack environmental support for the sustainability of agriculture and labor problems cause the result is not optimal. Jamal (2008) adds that rural development has a major constraint due to the unavailability of the grand strategy of rural development as a reference. In the previous research conducted by $\mathrm{Ma}$ et al. (S2015) for the research location of a rural area in China, the process which is done is the segmentation with a certain scale parameter value but there is only little information about the accuracy.

This study aims to segment the data object on aerial photographs of UAVs in particular rural area in Cianjur, West Java. It also aims to figure out the potency of UAV data to support the provision of spatial information in rural areas, which can be used for spatial planning and rural development programs in Indonesia. Rural areas are the focus of research due to their important role in national development. On the other hand, the research about spatial rural area with remote sensing is still rarely performed.

\section{Research Method Imagery Data}

The main data discussed for the classification of land use cover are data from the LSU-1 UAV acquired by Pustekbang LAPAN Team on March 4, 2013 at 10:24 pm as shown in Figure 2-1 those are the image data of RGB camera Canon S100 with a size of 4000 pixels x 3000 pixels, the spatial resolution of $16 \mathrm{~cm}$, in Cianjur Regency, West Java.

\section{Image Processing}

Land cover segmentation method of UAV data proposed in this study is a segmentation method with multiresolution segmentation algorithm. Image segmentation according to Cahyan et al. (2013) is the process of separating an object in the image with other objects or object with the background for further utilization.

Stages of the study as has been described in Figure 3 and the stages of data processing are,

\section{Image segmentation}

Scale Parameter is the level of inequal maximum (heterogeneity) in an object (Anonymous, 2014). Thus, the higher the number is, the more homogeneous the segmentation result is, while the smaller the scale parameter is, the more segmentation result there will be. Segmentation is performed with the scale parameter 300 and it is based on Sari and Dony's research (2014) for data processing UAV that uses this scale since the result of the image segmentation is accurately differentiated. In this research, it is also explained that the algorithm used is multiresolution segmentation.

This algorithm merges process pixels with the same criteria. We set the scale parameter to obtain the best segmentation results. The segmentation process is illustrated in Figure 2 (Anonymous, 2014). The algorithm used for segmentation is as written by Widodo et al. (2011), namely the K-Means algorithm. This algorithm classifies the object based on the attribut into $\boldsymbol{k}$ divider. This is a variation of probability maximization algorithm and the objective is to determine the $\boldsymbol{k}$. The assumption is that the object attribute format is a vector space. The goal is to minimize the difference in intra-cluster, or function

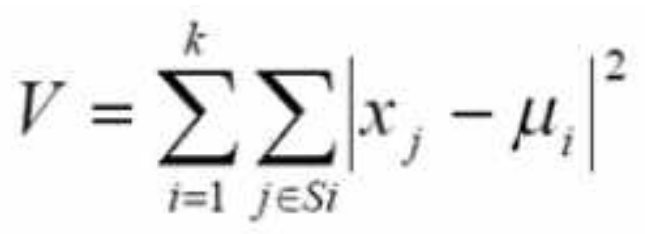

where there is $\boldsymbol{k}$ cluster $\boldsymbol{i} \boldsymbol{S}, \mathrm{i}=1,2, \ldots, \boldsymbol{k}$ and $\boldsymbol{\imath} \mathbf{1}$ are the center of an area or point from all points. 
Segmentation is also performed on some larger scale parameters than scale parameter 300 , those are 400 , 500 , and 600 to see the most accurate value.

\section{Measurement of accuracy.}

Segmentation result obtained using scale parameter is then tested for the level of accuracy. Accuracy test is very important here because visually the differences of segmentation results in each scale parameter are not very significant. Therefore, it is necessary to have an accuracy test process to determine the effectiveness of a scale parameter that is used for object segmentation. The data used for testing the accuracy are the results of visual interpretation from the experts as shown in Figure 4. Meanwhile, the object classes of land cover identified from the image consist of 7 classes as described in Table 1. Test accuracy used in this research is as conducted by Isti (2014) in her research. However, references in this research are not the field checks but they are the results of visual image interpretation.
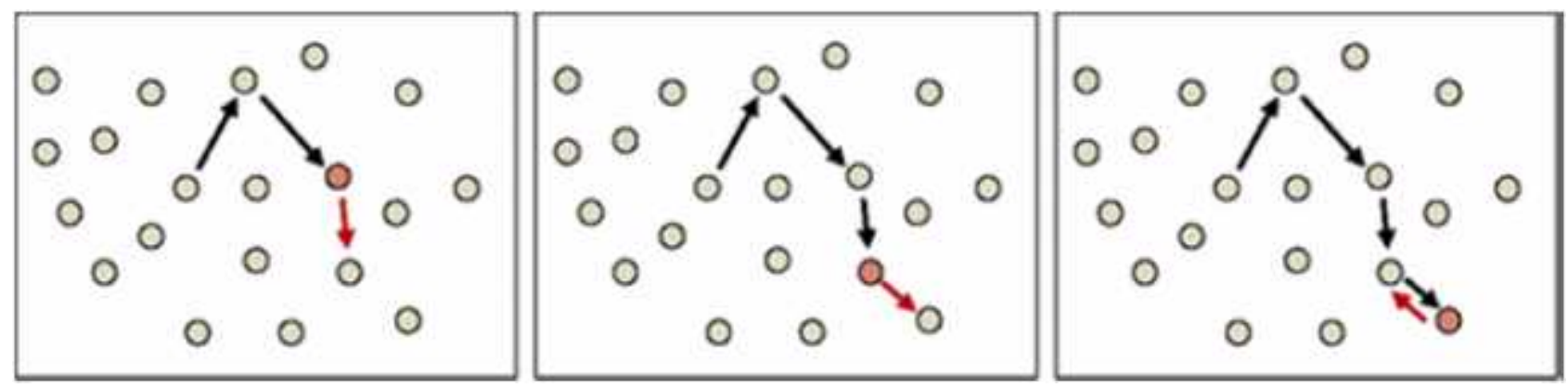

Figure 2. The process of pixels in the image in looking for the most similar pair in the segmentation process to obtain the best partner

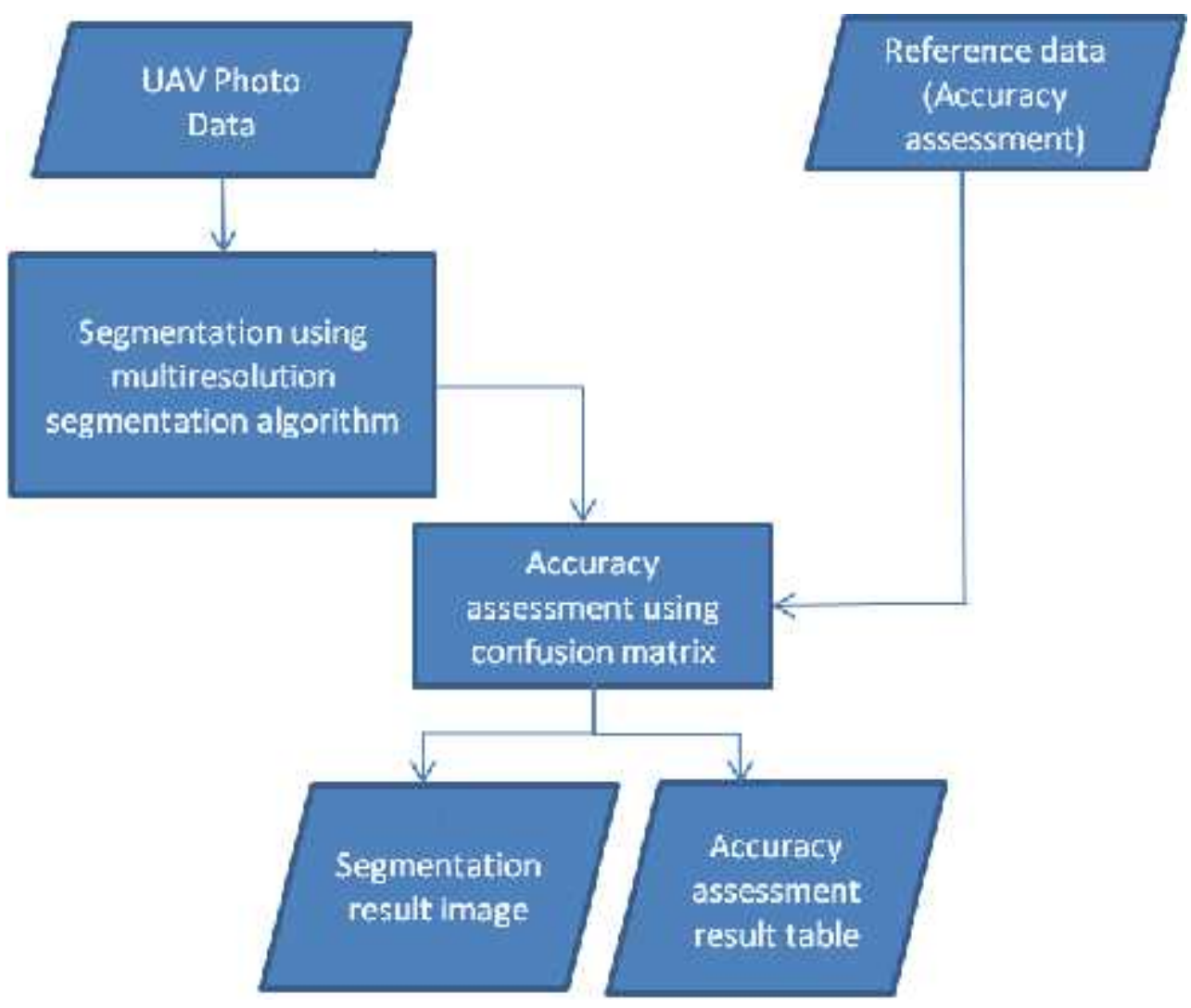

Figure 3. Segmentation stages of land cover UAV data. 
Table 1. Class objects category / land cover in the image and color grade trials on data test.

\begin{tabular}{ll}
\hline \multicolumn{1}{c}{ Classes } & Color grades \\
\hline 1. Vegetative ricefield 1 & \\
2. Vegetative ricefield 2 & \\
3. House 1 & \\
4. House 2 & \\
5. Tree & \\
6. Road & \\
7. Pond & \\
\hline
\end{tabular}

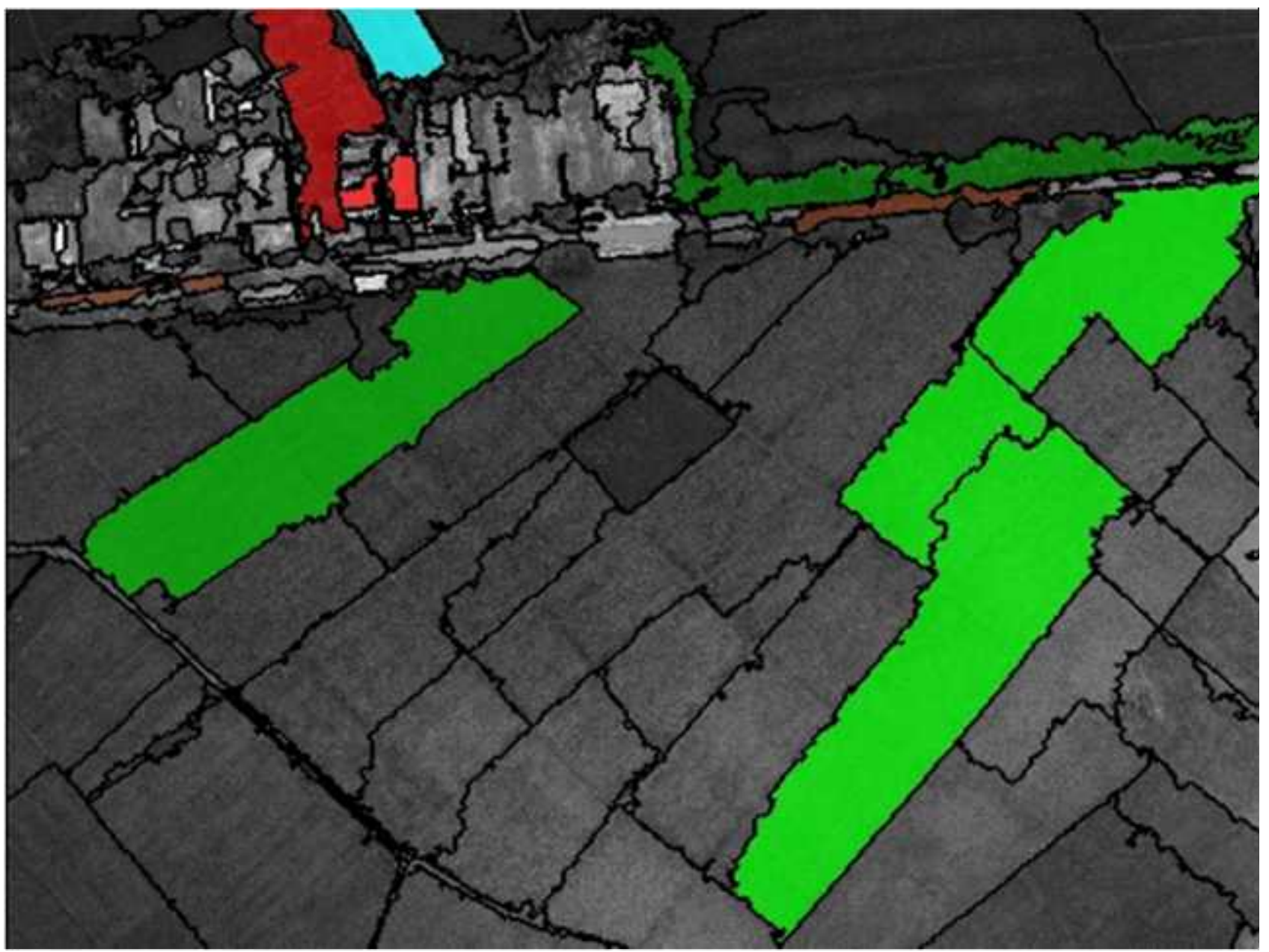

Figure 4. The data test as a result visual interpretation to test the accuracy of segmentation results 


\section{Findings and Discussion}

Image segmentation on UAV data is performed on the image by using the scale parameter in accordance with the object separation need. Result of the scale parameter 300 is shown in Figure 5, which produces 132 segmented objects. This process is performed quickly enough for about 1 minute. Visually, it is seen that the objects in the image is accurately separated. There are seven categories of object classes which are identified, namely rice vegetative 1 which is quite old, rice vegetative 2 which has a younger age of plants, home 1 with clay tile roof in light brick color, 2 house 2 with clay tile roof in dull brown, trees, roads, and ponds.

Based on the results_of segmentation in Figure 5, it is noted that segmentation can be applied to the image of UAV data. Delineation lines separate each different object. Visual characteristics as a differentiating parameter are color, pattern, roughness, dark - light, and shape. There are seven classes of objects which are identified and almost

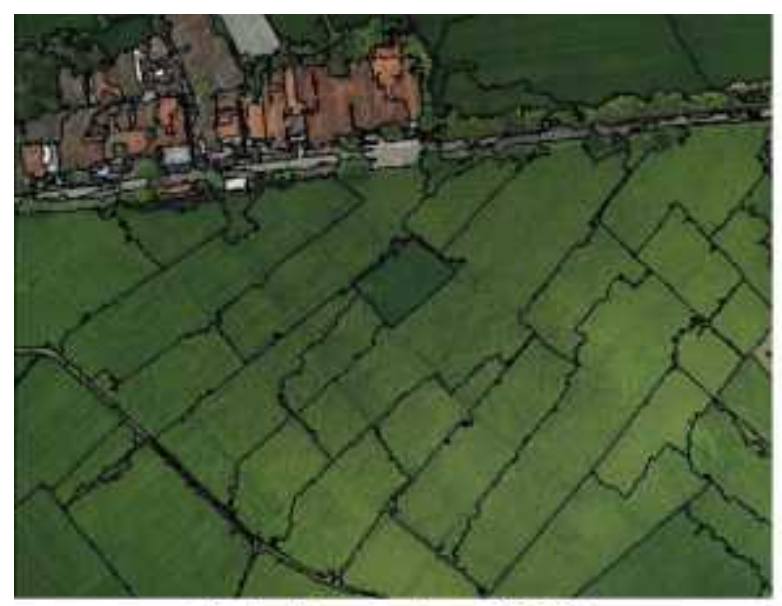

a. Scale Parameter of 300

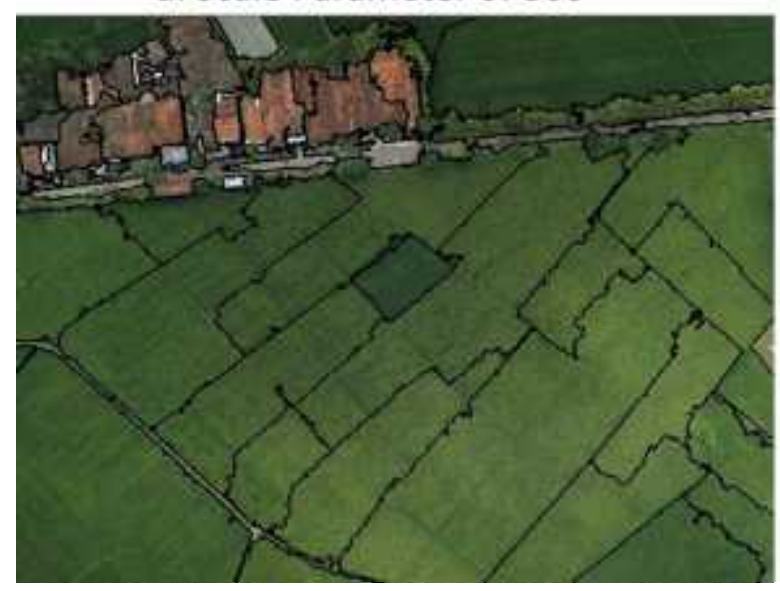

c. Scale Parameter of 500 entirely separated well. Proportion of wetland compared to other objects is greater because the research location is a rural area which is identical with the wetland as an area for citizens to do agriculture as their main jobs. For houses, trees, roads and ponds, separation of the object is not too complicated. Area the object is not too extensive; besides, the appearance of objects is quite different so that segmentation has good results. Unlike the case with wetland, rice fields have different growth time; similarly, it has the same condition with the wetland on the image. Visually, it can be observed that the ricefield which has been planted (in the vegetative phase) consists of two ages; ricefield which is still green and the one which begins to turn yellow but can not be harvested yet.

To obtain a better segmentation result, optimization of segmentation result should be performed. Optimization is a process to get the best results in a particular way. In the segmentation result with the scale parameter 400 , there are 78 objects. It is seen

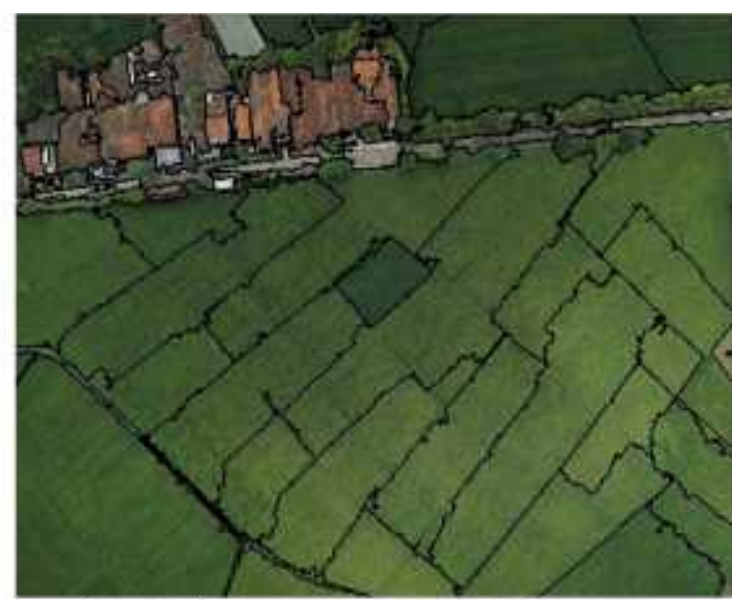

b. Scale Parameter of 400

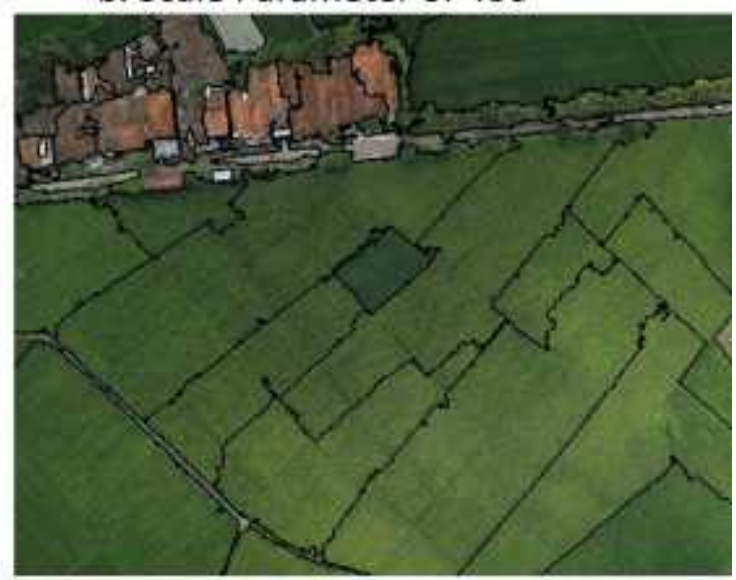

d. Scale Parameter of 600

Figure 5. Object segmentation result with Various Scale Parameter 
that after some parts of the ricefield are optimized, plants with the same growing age become into one polygon. Plants which have the same type and appearance as the image also experience polygon merger. Visually, the result of segmentation by scale parameter 400 is better so that It is said that by this scale parameter. the separation of rice fields and other objects is optimal. The trial is preceeded to the larger scale parameter. Test on the scale parameter 500 generates 57 objects. Then, for the scale parameter 600 , there are 46 separate objects. However, by the scale parameter 500 and 600 , more tree areas and rice fields are in one polygon.

The accuracy obtained from scale parameter 300 is $80.95 \%$ and this is a quite good result. However, from the segmentation result, there are still some ricefield polygons which have the same growing age are still segmented. It is because by this scale, value ranges of pixels of most similar neighbors is too small so that there is a little difference in distinguishing parameters such as color, pattern, roughness, dark light, and shape of the polygon. Ricefield is a hot issue in rural areas so that the separation of the objects of ricefields which are in the same growth time becomes something very crucial. It is one of the reasons for optimization.

Optimization of the result in this research is conducted by a trial of some scale parameter values to obtain the less segmentation object. Hence, some trials are performed on some values which are greater than 300. The optimization result is shown in Table 3, 4 and 5. Through the test result, it can be concluded that the most optimal value is 400 . This indicates that the scale parameter of 300 applied by Sari and Dony

Table 2. Accuracy of the Object Segmentation Result of UAV Photo Data Using Proposed Method (Scale Parameter 300)

\begin{tabular}{|c|c|c|c|c|c|c|c|c|}
\hline \multicolumn{9}{|c|}{ Reference (visual interpretation result) } \\
\hline \multirow{8}{*}{ 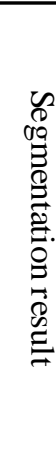 } & classes & $\begin{array}{l}\text { Vegetative } \\
\text { ricefield } 1\end{array}$ & $\begin{array}{l}\text { Vegetative } \\
\text { ricefield } 2\end{array}$ & Tree & $\begin{array}{c}\text { House } \\
1\end{array}$ & House 2 & Road & Pond \\
\hline & Vegetative ricefield 1 & 1 & & & & & & \\
\hline & Vegetative ricefield 2 & 2 & & & & & & \\
\hline & Tree & & & & & & & \\
\hline & House 1 & - & & & 2 & & & \\
\hline & House 2 & & & & & 1 & & \\
\hline & Road & & & & & & 2 & \\
\hline & Pond & & & & & & & 1 \\
\hline & Total & 3 & . & & 2 & 7 & 2 & 1 \\
\hline
\end{tabular}

Table 3. Accuracy of the Object Segmentation Result of UAV Photo Data Using Proposed Method (Scale Parameter 400)

\begin{tabular}{|c|c|c|c|c|c|c|c|c|}
\hline \multicolumn{9}{|c|}{ Reference (visual interpretation result) } \\
\hline \multirow{9}{*}{ 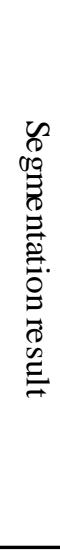 } & classes & $\begin{array}{l}\text { Vegetative } \\
\text { ricefield } 1\end{array}$ & $\begin{array}{l}\text { Vegetative } \\
\text { ricefield } 2\end{array}$ & Tree & $\begin{array}{c}\text { House } \\
1\end{array}$ & $\begin{array}{c}\text { House } \\
\quad 2\end{array}$ & Road & Pond \\
\hline & Vegetative ricefield 1 & 2 & & & & & & \\
\hline & Vegetative ricefield 2 & 1 & 1 & 1 & & & & \\
\hline & Tree & & & 2 & & & & \\
\hline & House 1 & & & & 2 & & & \\
\hline & House 2 & & & & & 1 & & \\
\hline & Road & & & & & & 2 & \\
\hline & Pond & & & & & & & 1 \\
\hline & Total & 3 & 1 & 3 & 2 & 1 & 2 & 1 \\
\hline & & Average & iccuracy & & & & & .47619048 \\
\hline
\end{tabular}


(2014) for UAV data with different objects is not necessarily optimal for the application in the UAV data with the same resolution but has a different object. Figure 5 shows the segmentation result on some scale parameter values. Scale parameter used beside 300 are 400, 500 and 600 .

In an accuracy test of scale parameter of 500, the accuracy value which is obtained is $88.09 \%$. Impairment of the value is because in house class 1 there is a separate house and it is included in other segments. At this scale parameter, there are tree areas and paddy fields located in a polygon. Accuracy test shows that the accuracy of the scale parameter value of 600 is to $88.09 \%$ which is similar with scale parameter 500. Thus, it can be seen that the most optimal scale parameter that is used for the data in this research is 400 . Table 2 shows how accuracy is obtained in the research by using scale parameters of 300 and the result is quite good that is $80.95 \%$. The amount of test data which are used as a reference for accuracy test are as many as 13 data from the seven classes of land cover objects. From the table it is shown that for ricefield vegetative one, there are there are three areas which become the data test. From those 3 areas, one is segmented into an appropriate age but the other 2 are segmented into another ages. It is influenced by the scale parameter of 300 which is pretty tight in searching the most similar partner. Ricefield vegetative 2 has 1 data test

Table 4. Accuracy of the Object Segmentation Result of UAV Photo Data Using Proposed Method (Scale Parameter 500)

\begin{tabular}{|c|c|c|c|c|c|c|c|}
\hline & \multicolumn{7}{|c|}{ Reference (visual interpretation result) } \\
\hline \multirow{9}{*}{ 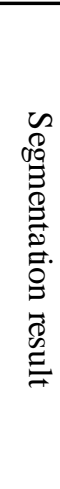 } & $\begin{array}{c}\text { classes Vegetative } \\
\text { ricefield } 1\end{array}$ & $\begin{array}{l}\text { Vegetative } \\
\text { ricefield } 2\end{array}$ & Tree & House 1 & House 2 & $\overline{\text { Road }}$ & Pond \\
\hline & Vegetative ricefield 1 & 2 & & & & & \\
\hline & Vegetative ricefield 2 & 1 & 1 & 1 & & & \\
\hline & Tree & & 2 & 2 & & & \\
\hline & House 1 & & & & 2 & & \\
\hline & House 2 & & & & & 1 & \\
\hline & Road & & & & & & 2 \\
\hline & Pond & & & & & & 1 \\
\hline & Total & 3 & $\overline{1}$ & $\overline{3}$ & $\overline{2}$ & 1 & $\overline{2}$ \\
\hline & Average accuracy & & & & & & 90.47619048 \\
\hline
\end{tabular}

Table 5. Accuracy of the Object Segmentation Result of UAV Photo Data Using Proposed Method (Scale Parameter 600)

\begin{tabular}{|c|c|c|c|c|c|c|c|c|}
\hline \multicolumn{9}{|c|}{ Reference (visual interpretation result) } \\
\hline \multirow{10}{*}{ 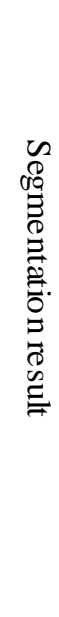 } & kelas & $\begin{array}{c}\text { sawah } \\
\text { vegetatif } \\
1\end{array}$ & $\begin{array}{c}\text { sawah } \\
\text { vegetatif } \\
2\end{array}$ & pohon & $\begin{array}{c}\underset{1}{\text { rumah }} \\
1\end{array}$ & $\begin{array}{c}\text { rumah } \\
2\end{array}$ & jalan & empang \\
\hline & Vegetative ricefield 1 & 2 & & & & & & \\
\hline & Vegetative ricefield 2 & 1 & 1 & & & & & \\
\hline & Tree & & & 3 & & & & \\
\hline & House 1 & & & & 1 & & & \\
\hline & House 2 & & & & 1 & 1 & & \\
\hline & Road & & & & & & 2 & \\
\hline & Pond & & & & & & & 1 \\
\hline & Total & 3 & 1 & 3 & 2 & 1 & 2 & 1 \\
\hline & & $\mathrm{Av}$ & age accur & & & & & 88.0952381 \\
\hline
\end{tabular}


and it is segmented appropriately. Furthermore, in object tree, there three data tests and only one is segmented appropriately. Object house 1 and house 2 have a different roof character and both are segmented accurately. Roads and ponds are also segmented appropriately.

In the accuracy test, the result shows that the accuracy is increasing from $80.95 \%$ to $90.47 \%$ on the scale parameter of 400 . Improvement on accuracy values is shown in the ricefield vegetative 1 and trees. In the segmentation result, colors and patterns on wetland in the same growth time are properly identified so that they can be separated well. The higher scale parameter value makes heterogeneity tolerance increases as well so that the rest of the previous polygons become one polygon on this scale parameter of 400. Importance of segmentation validity for wetland in this research is because this land is one of characteristics of rural areas. Rice fields with the same age indicate the same owner as well. An accurate segmentation capability is potential to help the calculation of the wetland with the same ownership for the tax and harvest.

Parsa's research (2013) which examines the segmentation optimization on Landsat and Quickbird data finds best results by changing the parameters of color, shape, compactness, and smoothness with accuracy up to $96.3 \%$. In contrast Parsa's research, in this research parameter which is changed only scale parameter but its accuracy has reached $90.47 \%$. Application of the easier method with fairly high accuracy result in this research demonstrates that the method used is accurate for segmentation. In addition, the method in this research is quite reliable when it takes a short time for data processing.
Although accuracy has not reached $96.3 \%$, but the ease of the method and the short time required become one advantage of the proposed method in this research. Meanwhile, Ma (2015) applies GEOBIA and performs segmentation on highresolution imagery from the UAV data by changing some parameters such as scale parameter and training set ratio. The research obtains an accurate result up to $90 \%$. It only uses one parameter that is the scale parameter and the result is quite accurate so that it can be recommended to use this method due to the object separation with little time allocation.

\section{Conslusion and Recommendation}

Object segmentation using a scale parameter value of 400 reaches an accuracy value of $90.47 \%$ which indicates that the object segmentation process in rural areas can be done well and accurately. It shows that the method proposed in this research is able to support the provision of spatial information in rural areas. It is needed to explore further influence of the object characteristic on the image that affects the size of the optimal scale parameter for the object segmentation.

\section{Acknowledgement}

Our gratitude is delivered to Drs. Gunawan Setyo Prabowo, M.T., Head of Aviation Technology Lapan and Drs. Ari Sugeng Budiyanta, M.Sc., Head of Avionics Technology of Aviation Technology Lapan who have provided the opportunity to use the UAV data of Lapan aerial photographs for the purpose of this research. Similarly, a huge thank is also delivered to Dr. Cynthia Henny for the guidance in making this paper.

\section{References}

Anonim, 2014. ECognition Developer Reference Book 9.0, Trimble Documentation, München, Germany.

Badan Perencanaan Pembangunan Nasional. 2010. Kajian Pembangunan Perdesaan dengan Integrasi Pembangunan Wilayah dan Kegiatan Sektoral.

Bemis, S., Steven M., Darren T., Mike R. J., Sinan A., Sam T. T., Hasnain A. B. 2014. Ground-based and UAVBased Photogrammetry: A multi-scale, High Resolution Mapping Tool for Structural Geology and Paleoseismology. Journal of Structural Geology 69 (2014), Pp. 163-178.

Cahyan, P. A., Aswin, M., Mustofa, A. 2013. Segmentasi Citra Digital dengan Menggunakan Algoritma Watershed dan Lowpass Filter sebagai Proses Awal. Jurnal Mahasiswa Teknik Elektro Universitas Brawijaya Vol. 1 No. 52013

Diaz-Varela, P. J. Zarco Tejada, V. Angileri, P. Loudjani. 2014. Automatic Identification of Agricultural Terraces through Object Oriented Analysis of Very High Resolution DSMs and Multispectral Imagery Obtained from an Unmanned Aerial Vehicle. Journal of Environmental Management 134 (2014), Pp. 117-126. 
Dony K.,2014. Teknologi Akuisisi Data Pesawat Tanpa Awak dan Pemanfaatannya Untuk Mendukung Produksi Informasi Penginderaan Jauh, Inderaja, Vol. V, No. 7, Pp.24-31.

Flanders, D., M. Hall-Beyer, J. Pereverzoff. 2003. Preliminary Evaluation of eCognition Object-based Software for Cut Block Delineation and feature extraction. Canadian Journal of Remote Sensing Vol. 29, No. 4, Agustus 2003.

Gao Y., J. F. Mas, I. Niemeyer, P. R. Marpu, J. L. Palacio. 2007. Object-Based Image Analysis For Mapping Land-Cover In A Forest Area. Proc. of $5^{\text {th }}$ International Symposium on Spatial Data Quality 2007, ITC, Enschede, The Netherlands

Hartono. 2010. Penginderaan Jauh dan Sistem Informasi Geografi Serta Aplikasinya di Bidang Pendidikan dan Pembangunan. Seminar Nasional Penginderaan Jauh dan SIG 2010

Isti, A. Y. 2014. Tugas Akhir: Aplikasi Penginderaan Jauh Dan Sistem Informasi Geografis Untuk Pemetaan Zonasi Kerentanan Banjir Di Kabupaten Sragen. Yogyakarta: Universitas Gadjah Mada. http:// e $\quad \mathrm{t} \quad \mathrm{d} \quad . \quad \mathrm{u} \quad \mathrm{g} \quad \mathrm{m} \quad . \quad \mathrm{a} \quad \mathrm{c} \quad . \quad \mathrm{i} \quad \mathrm{d} /$ index.php?mod=penelitian_detail\&sub=PenelitianDetail\&act=view\&typ=html\&buku_id=64631\&obyek_id=4 diunduh 1 Februari 2015

Jamal, E. 2008. Kajian Kritis Terhadap Pelaksanaan Pembangunan Perdesaan di Indonesia. Forum Agro Ekonomi Vol. 26 Nomor 22008.

Khomarudin, M. R. 2014. Evaluasi Kejadian Banjir Kampung Pulo Dki Jakarta dan Analisis Pengurangan Resikonya Berbasis Data Unmanned Air Vehicle (UAV) Dan Penginderaan Jauh Resolusi Tinggi, Proseding Seminar Nasional Penginderaan Jauh 2014, Bogor.

Ma, L., Liang C., Manchun L., Yongxue L., Xiaoxue M. 2015. Training Set Size, Scale, and Features in Geographic Object-Based Image Analysis of Very High Resolution Unmanned Aerial Vehicle Imagery. ISPRS Journal of Photogrammetry and Remote Sensing 102 (2015), Pp. 14-27.

Marpu, P. R., 2009. Thesis: Geographic Object-based Image Analysis,Faculty of Geosciences, Geo-Engineering and Mining of the TechnischeUniversit" atBergakademie Freiberg Germany.

Integration, The Int. Archives of the Photogrammetry, Remote Sensing and Spatial Information Sciences. Vol. XXXVII. Part B1. Beijing 2008.

Muryani, C. 2010. Analisis Perubahan Garis Pantai Menggunakan SIG serta Dampaknya Terhadap Kehidupan Masyarakat di Sekitar Muara Sungai Rejoso Kabupaten Pasuruan. Jurnal Forum Geografi Vol. 24, No. 2,pp. 173-182.

Parsa M., 2013.Optimalisasi Parameter SegmentasiUntukPemetaanLahanSawahMenggunakan Citra Satelit Landsat (StudiKasus Padang Pariaman, Sumatera Barat Dan Tanggamus, Lampung, Jurnal Inderaja dan Lahta Citra Digital, Vol.10, No.1, pp.31-39.

Rudianto, B. 2010. Analisis Ketelitian Objek pada Peta Citra Quickbird RS 0,68 m dan Ikonos RS 1,0 m. Jurnal Rekayasa, Institut Teknologi Nasional, No. 3, Vol. XIV Juli - September 2010.

Sahid. 2009. Penafsiran Luas Bidang Dasar Tegakan Pinus Merkusii Menggunakan Foto Udara di Kesatuan Pemangkuan Hutan (KPH) Kedu Perum Perhutani Unit I Jawa Tengah. Jurnal Forum Geografi Vol.23, No.2, pp. 112-122.

Sari, N. M., Dony K. 2014. Klasifikasi Lahan Berbasis Obyek Pada Data Foto UAV untuk Mendukung Penyediaan Informasi Penginderaan Jauh Skala Rinci. Jurnal Inderaja dan Lahta Citra Digital, Vol.11, No.2, pp.114127.

Shofiyati, R., 2011. Teknologi Pesawat Tanpa Awak Untuk Pemetaan dan Pemantauan Tanaman Dan Lahan Pertanian. Informatika Pertanian, Vol. 20 No.2, Desember 2011: 58 - 64.

Widodo, S., Hidayatno, A., Isnanto, R. R. 2011. Tugas Akhir: Segmentasi Citra Menggunakan Teknik Pemetaan Warna (Color Mapping) Dengan Bahasa Pemrograman Delphi. Semarang: Universitas Diponegoro http:/ /eprints.undip.ac.id/25765/ diunduh 26 Desember 2014

Xiaoxia, S., 2005.A Comparison Of Object-Oriented And Pixel-Based Classification Approachs Using Quickbird Imagery,ISPRS Archives- Volume XXXVI-2/W25. 